13The European Journal of

Humour Research 8 (2) 25-48

www.europeanjournalofhumour.org

\title{
The role of secondary incongruities in cartoon appreciation
}

\author{
Beatriz Carbajal-Carrera \\ The University of Sydney, Australia \\ beatriz.carbajal@sydney.edu.au
}

\section{Olga Sánchez Castro}

Flinders University, Australia

olga.castro@flinders.edu.au

\begin{abstract}
Failed humour in conversational exchanges has received increasing attention in humour research (see Bell 2015; Bell \& Attardo 2010). However, tensions between what constitutes successful and failed humour have yet to be fully explored outside conversational humour. Drawing on Hay's (2001) classification of humour stages and using a socio-cognitive approach to pragmatics to examine responses from Spanish L1 and L2 users to differing combinations of structural and content features in cartoons, the present study aims to explore what factors contribute to successful and failed responses to multimodal humour. Previous research has predominantly investigated the role of caricature as one of the prototypical features of cartoons affecting humour communication, suggesting that this feature plays an active role in the recognition of the humoristic genre (Padilla \& Gironzetti 2012). Findings from the present study indicate that caricature operates not only in the recognition, but also in the understanding and appreciation stages. In particular, our results point to two other roles of caricature as a secondary incongruity and as a factor that can trigger appreciation through empathy and/or a sense of superiority. Importantly, this investigation indicates that the presence of secondary incongruities can compensate for a partial lack of understanding, highlighting the relevance that this type of incongruity has in humour appreciation.
\end{abstract}

Keywords: secondary incongruity, cartoons, contextualisation indexes, cognitive scripts, failed humour, empathy, socio-cognitive approach.

\section{Successful and failed humour in cartoons}

Traditional pragmatic approaches explain communication based on cooperation and relevance principles (Grice 1975; Sperber \& Wilson 2005). As language users, we acknowledge and follow the conventions that allow communicative success in its neutral mode, also known as the 
bona-fide mode (Raskin 1992). Humour, on the other hand, is considered a marked mode of communication (non-bona fide) that infringes universal rules of human interaction, as it disrupts basic communicative principles such as the Cooperative Principle (Grice 1975), Politeness Principle (Leech 1983) and Appropriateness Principle (Gutiérrez 2006). According to this view, failed humour — understood as an unsuccessful attempt at humour (Bell 2014) - is often explained by arguing that humour does not follow conventional communication principles (Iglesias Casal 2007). However, establishing the success/failure of humour on the basis of whether it follows cooperation principles is problematic and artificial, given that the ability of communicative principles to fully explain all kinds of interaction has been questioned in the literature (Haugh 2008; Kecskés 2010; Gil 2019). As argued by Gil (2019: 159), if cooperation and relevance would operate in every communication instance, as claimed by Gricean pragmatics, there would be no place in interaction for weak implicatures, understood as interpretations evoked by the audience independently from the text's intentions.

According to traditional pragmatics that explain communication based on cooperation and relevance principles (Grice 1975; Sperber \& Wilson 2005), successful interaction depends on interpreting a text's intentional meaning. We believe that, while providing an important account of cooperative and intentional communication, traditional pragmatic approaches to communication are limited at explaining humour interaction when interpretations do not agree with communicative intentions. Specifically, can these communication principles explain humour appreciation despite partial understanding of cultural references?

In humour research, Hay (2001) proposed that any successful humour attempt necessitates a lineal progressive engagement in the recognition, understanding, appreciation and agreement stages. ${ }^{2}$ That is, users need, in an orderly manner, to overcome the recognition and understanding stages to reach an appreciation of humour. Other authors have contested this linear stage progression (Bell 2007; Bell \& Attardo 2010) and have shown that stages are not necessarily linear, nor do they even occur in a separate order but rather, in a dynamic, notmutually exclusive manner.

At the recognition stage, the multimodal textual structure of cartoons has an immediate visual impact on the identification of their comic intention compared to other genres where the structure itself is less indicative of the purpose (i.e. comic monologue vs. serious monologue). A genre has been defined as a concurrence of features (linguistic and structural elements, topic, situational context and intention) recognisable as prototypical by a speaking community (Paltridge 1995) and a set of expectations related to the interpretation of a text (Neale 1980) given the active role it plays in triggering its anticipated characteristics. At a pragmatic level, genre recognition not only activates sociocultural expectations but also orientates the audience's attitudes. This can be exemplified in our predisposition to humour in comedy as opposed to our initial attitudes towards tragedy or epic (Aristotle 1974). Despite the expected differentiation between humour and non-humour genres, this theoretical division is admittedly artificial since apparently serious genres, such as dialogue, can include puns or any other humoristic mechanism (Ruiz Gurillo 2012).

Studies on genre recognition have also pointed towards the relevance of contextualisation cues for the identification of humour intention (see Drew 1987; Genette 2001; Kotthoff 2006; Bell 2007; Padilla \& Gironzetti 2011; Carbajal-Carrera 2013; Gironzetti 2013). Contextualisation indexes are prototypical and concurring characteristics that activate readers' expectations regarding the internal structure, content or intent of a given text-type. In humour

\footnotetext{
${ }^{1}$ Failed humour is defined as a failure in the identification of the humour intention or the processing of its information by participants in a communicative exchange (Bell \& Attardo 2010).

${ }^{2}$ For the purposes of this study, agreement is embedded within appreciation as it is considered an opportunity to confirm appreciation. Bell (2015) adds a participation stage that has been discarded in this study, given the limitations of participation that cartoons offer.
} 
genres, contextualisation indexes point to their non-bona fide mode. Gironzetti (2013) identifies seven contextualisation indexes in cartoons (section title, caricature, signature, title, external frame, decorative coloured text and balloons), and specifies that, although the presence of all these indexes is not mandatory to constitute a humour text type, several indexes must simultaneously concur to guarantee recognition of the humorous intention. The potential of contextualisation cues to influence other humour stages is, however, yet to be investigated.

Closely related to contextualisation indexes, content indexes are textual elements embedded in cartoons, such as iconic images of keywords that provide information on the humorous communicative intent. Within humour content, access to cognitive scripts, defined as internalised knowledge structures that represent an aspect of the world (Taylor 2014), determine humour understanding (see Attardo 1994, 2002; Raskin 1985). These cognitive scripts have been classified into four categories: a) general or universal knowledge, b) restrictive or culturebound knowledge, c) linguistic knowledge and d) individual knowledge referring to opinions and attitudes (Attardo 1994). According to the General Theory of Verbal Humour (Attardo \& Raskin 1991), access to these cognitive scripts (and, in turn, to script opposition) is the most important factor in humour understanding out of all six knowledge resources (language, narrative strategy, target, situation, logical mechanism and script opposition).

In second language learning research, the concept of cognitive scripts has been adapted to different types of content so that these could be progressively introduced according to the language learner's linguistic proficiency level. Schmitz (2002), for example, suggests introducing universal humour at beginner proficiency levels, moving towards cultural humour in intermediate levels, and linguistic humour at more advanced levels. The classification derived from the types of cognitive scripts distinguished by Attardo (1994) has been applied to jokes in second language teaching for the standardisation of humour content according to varying linguistic proficiency levels (Schmitz 2002; Carbajal-Carrera 2012). However, this classification has yet to be applied to multimodal humour, in order to explore the relation between cartoon textual characteristics and responses to humour. As for differences in responses to humour by L1 and L2 users, research on oral humour has identified only quantitative differences in relation to failed humour (Bell \& Attardo 2010). Whether this is the case in multimodal cartoon text-type humour also remains to be investigated.

In the research on humour appreciation, three factors have been identified as the main elements that can trigger successful appreciation: superiority (Hobbes 1812; Bergson 1899; Gruner 1978), relief (Spencer 1911; Freud 1967; Bakhtin 1984) and incongruity (Koestler 1969; Nerhardt 1976; Attardo 2014). Superiority can, for example, be identified in jokes based on nationality, when characters are described stereotypically; relief can be identified in black humour that contains references to social taboos; and incongruity can be seen in the plot twist of punch lines. Although most studies have chosen to single out one of these three factors in order to explain appreciation, it has been argued that it is possible to find these three elements concurrently in humour texts (Martin 2007; Milner Davis 2015).

The concept of incongruity, understood as a lack of logical relation among ideas and characters or in relation to their communicative context (Gruner 1978), is particularly relevant to the success of humour, given the critical role it plays in the appreciation stage as identified by the General Theory of Verbal Humour (Attardo \& Raskin 1991).Traditionally, incongruity has been associated with script opposition, but some authors (see Viana 2010; Ritchie 2013) claim that together with script opposition, the presence of secondary incongruities, defined as illogical relations that are not resolved, can further enable humour appreciation.

Although contextualisation cues, cognitive scripts and incongruity have proved to be key factors in successful humour, a theory of humour cannot be complete without considering both successful and failed attempts at conveying humour (Bell 2014). There is, however, little research on failed humour, while most literature focuses on successful oral humour and on the 
factors that contribute to this positive outcome. Studies on failed humour indicate that failed humour can have an important negative impact on interlocutors, as it challenges both the speaker and the hearer, who risk being labelled as dull or as a bad audience respectively (Bell 2014). Therefore, given the potential negative effect of failed humour on social acceptance, factors that drive intention and attention, such as self-image (Austin 1962; Brown \& Levinson 1987), should be considered when exploring humour appreciation.

Research on failed humour has identified failure in all processing stages (Bell 2014), whereas the interactive dynamics between these stages have received little attention. This points strongly to the need to better understand the specific factors involved in the success or failure in humour that are key in its different processing stages. A competence-oriented account of types of failed humour by Bell \& Attardo (2010) includes seven types of failure: (1) Unable to hear or process the text, (2) Unable to understand words/connotations, (3) Unable to understand the pragmatic meaning, (4) Unable to recognise the humorous mode, (5) Unable to understand the incongruity, (6) Unable to appreciate the humour, and (7) Unable to join. From these scenarios, types (2), (3), (5) and (6) are expected to cause failed humour in cartoons, whereas the rest of the scenarios do not apply to the cartoon genre.

The focus of failed humour research has so far been placed on responses to non-appreciated verbal humour solely from a sociolinguistic perspective. For instance, Bell's (2009) study, investigating responses to a particularly dull joke and analysing the effect of age, gender and interpersonal relations in failed humour, found that the most negative reactions are reported by close interlocutors. Lockyer \& Pickering (2001) also studied reactions to offensive humour and linked the success or failure of the comic intention to the interlocutors' personal ethics. Both studies, however, depart from a focus on textual characteristics that anticipate a lack of appreciation-uninteresting and offensive content respectively-instead of measuring the impact that varying textual contents can have on the audience, as proposed by the present study.

Most empirical research in failed humour has focused on the response of either L1 users or L2 users to verbal humour (Bell 2002; 2009; 2013). However, research contrasting humour responses by both groups of speakers as well as research on L2's reactions to compensate for a lack of common ground is yet to be systematically explored. The analysis of L2 users' response to cartoon humour in this study does not aim to investigate language learning development but rather, to ascertain the impact that differing access to both linguistic scripts and restrictive knowledge scripts can have on the successful or failed humorous intent. As noted by Bell (2014), the current virtual spread of information has exposed "the issue of humour that succeeded in its original context but failed when met by a broader audience". In this context of online data overload, the relevance of attention practice when processing information is highlighted. The present study explores the tensions between intention and attention in cartoons.

\section{Content and structure in cartoons}

The present study adopts a socio-cognitive approach (SCA) to pragmatics that considers both societal and individual factors in communicative processes in order to investigate the understanding and appreciation of graphic humour. Within this approach, there is an interplay between intention-oriented practice and attention-oriented practice (Kecskes 2010). SCA has been adopted because of its holistic take on the communicative processes, including both social aspects (cooperation, intention, and relevance) and individual aspects (egocentrism, attention and salience). Given the role of both relevance (importance) (Sperber \& Wilson 1995) and salience (prominence) (Kecskes 2010) in communication, both the cartoonist and the reader rely on the most accessible and prominent meaning conveyed in the process involving the cartoon production and interpretation (Gil 2019). In cartoons, the core intention-oriented practice is 
articulated by the main incongruity that is present in script opposition. In contrast, the attentionoriented practice may or may not coincide with the main incongruity. In the present study, we hypothesise that when attention is not oriented towards the intentional meaning, secondary incongruities may explain an independent interpretation.

Research on graphic humour has proposed different cartoon typologies based on the wide range of content and structure characteristics that can be present in cartoons. Content typologies of humour include those proposed by Carretero-Dios (2010), Ruch (1992), Hempelmann \& Ruch (2005), Attardo (1994) and Schmitz (2002), as seen in Table 1. For the purposes of this study, content typologies have been grouped around the superiority, relief and incongruity theories and the latter have been selected given their relevance for comparing intention and attention in two cohorts with differing cultural and linguistic backgrounds. Since access to cognitive scripts depends on cultural, linguistic and individual factors, as claimed by Attardo (1994), with the aim to report on responses to cartoons, different types of knowledge scripts should be tested.

Table 1. Cartoon typologies according to their content

\title{
CONTENT
}

\author{
Superiority Theories \\ feminine/masculine denigration (Carretero-Dios 2010)
}

\author{
Relief Theories \\ sexual (Ruch, 1992; Hempelmann \& Ruch 2005) \\ sexual / black (Carretero-Dios et al. 2010)
}

\section{Incongruity Theories (scripts)}

general / restricted / linguistic / individual (Attardo 1994)

universal / cultural / linguistic (Schmitz 2002)

In addition to content characteristics, cartoon structure also contributes to the correct interpretation of humorous intent. Structure typologies of humour include those proposed by Freud (1905), Ruch (1992) as well as Hempelmann \& Ruch (2005). Out of the seven contextualisation indexes identified by Gironzetti (2013) as shaping the structure of cartoons (i.e. section title, caricature, signature, title, external frame, decorative coloured text and balloons), this study focuses on caricature because of its productive operability at different processing stages. The relevance of caricature as a contextualisation index has been addressed in pragmatics mainly in relation to the recognition of humorous communication (Genette 2001; Padilla \& Gironzetti 2012; Gironzetti 2013). In contrast, the main interest of this study lies in exploring the impact of caricature on the understanding and appreciation stages of multimodal humour in cartoons. Caricature ${ }^{3}$ is defined as "a genre of drawings, cartoons, and prints that include images of human faces and physiques that are grossly distorted and exaggerated for the purposes of a satirical or comic effect" (Klein 2014:103).

In order to explore factors that could affect participants' appreciation, two subtypes of distortion were differentiated within caricature. Observing the caricature in the cartoons selected by this study and following the American Psychological Association's terminology (2007), personification and dehumanisation were selected as two variations of caricature. The former

\footnotetext{
${ }^{3}$ Current cartoons have been claimed to have evolved from caricature, where the term refers no longer to a genre but to a prototypical feature (Edwards, 2014).
} 
type presents the portrayal of a non-human entity with human features and the latter, the depiction of human characters with deformed, exaggerated, or animalised features. This same dichotomy has been applied to Gary Larson's cartoons by Minahen (1997), who coined the term antihumans for human characters with distorted animalised features in contrast with the term humanimals or animated animal characters.

Personification can play an important role in cartoon appreciation due to its potential ability to foster empathy, as studies in graphic multimodal texts have indicated (Keen 2001; CarbajalCarrera 2015). The present study assumes that appreciation can manifest in the form of an emotional response, as argued by Warren \& McGraw (2014), who claim that appreciation manifestations can be physical, cognitive, or emotional. That is, the readers' ability to put themselves in the shoes of the cartoon character (i.e. when the reader experiences empathy as defined by Light et al. 2009) may facilitate successful appreciation of caricature humour. Investigating this potential correlation between personification, empathy, and successful appreciation in cartoon humour is therefore a central object of interest in the present study.

\section{Methodology}

The aim of this study is to explore the impact that different types of content indexes and contextualisation indexes can have, with a focus on knowledge scripts and personification/dehumanisation respectively, on the success or failure of cartoon understanding and appreciation by Spanish L1 and L2 users. Specifically, this paper aims to explore whether L1 and L2 humour understanding and appreciation in cartoons is affected by their inherent textual characteristics and whether the same textual characteristics are perceived to have a similar or different effect on the two groups of language users. By comparing L1 and L2 responses to humour, we aim to explore any potential qualitative differences among these cohorts. Bell \& Attardo (2010: 441) have argued that, against the common assumption, differences in conversational humour are merely quantitative:

the easily observed and commonsensical observation that NNSs have more trouble in understanding humour than NSs appears to reflect merely a quantitative and not a qualitative phenomenon. To put it differently, these data suggest that NNSs do not fail differently, they just fail more.

The present study will explore this quantitative/qualitative contrast within the context of cartoons' multimodal humour. For the purposes of this study, "humour understanding" refers to the comprehension of the cartoon without needing additional information, and "humour appreciation refers" to its valorisation as funny.

The following two research questions were designed to investigate elements relevant to the effect that different content and structure indexes of stimuli cartoons can have on the understanding and appreciation stages of humour competence: (1) "What textual elements contribute to humour understanding and appreciation of selected cartoons by the L1 and L2 participant users?" Since the appreciation of humour despite a lack of understanding has been reported in oral humour (Bell 2017), a second aim of this study is to explore this possibility in cartoons. Research question (2): "Does cartoon appreciation require complete understanding?" seeks to determine whether understanding must always precede appreciation in successful graphic humour.

The stimuli for the exploration of humour understanding and appreciation by the L1 and L2 participants consisted of 14 cartoons using Spanish as written text and caricature as visual text. As specified in Table 2, the cartoons selected represent examples of humour that contain at least 
one of the three content text type characteristics (i.e. cultural, linguistic and universal) of graphic humour identified in the literature (Attardo 1994; Schmitz 2002), and caricatures used in the 14 cartoons belong to either one or both structure text subtypes (i.e. personification and dehumanisation) according to the definition proposed by the American Psychological Association (2007).

Table 2. Content and structure characteristics of cartoons (C)

\begin{tabular}{|c|c|c|c|c|c|}
\hline \multicolumn{4}{|c|}{ CONTENT } & \multicolumn{2}{|c|}{ STRUCTURE } \\
\hline & Cultural & Linguistic & Universal & $\begin{array}{c}\text { Dehumanisatio } \\
n\end{array}$ & $\begin{array}{l}\text { Personificati } \\
\text { on }\end{array}$ \\
\hline $\mathrm{CO}^{4}$ & 1 & 0 & 0 & 1 & 0 \\
\hline$\underline{\mathrm{CO} 2}$ & 1 & 0 & 0 & 0 & 0 \\
\hline$\underline{\mathrm{CO} 3}$ & 1 & 0 & 0 & 1 & 0 \\
\hline$\underline{\mathrm{CO4}}$ & 0 & 1 & 0 & 1 & 0 \\
\hline$\underline{\mathrm{COS}}$ & 1 & 0 & 0 & 1 & 0 \\
\hline$\underline{\mathrm{CO6}}$ & 1 & 0 & 0 & 0 & 1 \\
\hline $\mathrm{CO}$ & 1 & 0 & 0 & 1 & 0 \\
\hline$\underline{\mathrm{CO}}$ & 1 & 1 & 0 & 1 & 1 \\
\hline$\underline{\mathrm{COg}}$ & 0 & 0 & 1 & 1 & 0 \\
\hline C10 & 0 & 0 & 1 & 1 & 1 \\
\hline C11 & 1 & 1 & 0 & 0 & 1 \\
\hline C12 & 0 & 0 & 1 & 1 & 0 \\
\hline$\underline{\mathrm{C} 13}$ & 1 & 1 & 0 & 1 & 1 \\
\hline$\underline{\text { C14 }}$ & 0 & 0 & 1 & 1 & 1 \\
\hline
\end{tabular}

${ }^{4}$ Table items $\mathrm{C} 01$ to $\mathrm{C} 14$ contain embedded links for each of these selected cartoons taken from the sourced Dosis Diarias web site http://www.dosisdiarias.com/, with the exception of C02. A link to an external web site page for $\mathrm{C} 02$ is also embedded in the corresponding table item. 
The 14 cartoons were selected from Dosis Diarias, a series authored by cartoonist Alberto Montt. The selection of texts authored by this single author provides a consistent basis of recurrent features. Among them, a cartoon's contextualisation indexes can vary from author to author, but are generally stable in a single author. Within the uniformity and internal coherence of this work, the selected 14 cartoons use a wide repertoire of humoristic resources representing, in turn, a range of different types of content/knowledge scripts (more accessible to less accessible) and structure indexes related to dehumanisation and personification of depicted caricatures. It should also be noted that the selected cartoons involve the use of numerous references to restricted knowledge scripts (encyclopaedic and sociocultural) and linguistic scripts (see Figure 1). This is particularly important for the present investigation, given that, while encyclopaedic references imply a challenge for all language users, sociocultural and linguistic references entail a further challenge for L2 users. For instance, in Figure 1, entitled 'The elm loses its patience', the balloon reads '-I do not provide pears, you get it? I-do-notprovide-pe-ars'. The understanding of the sociocultural and linguistic scripts embedded in the text requires access to the Spanish-language proverb No pidas peras al olmo ('Do not ask for pears from the elm tree' for a literal translation and 'Do not expect the impossible' for a communicative translation).

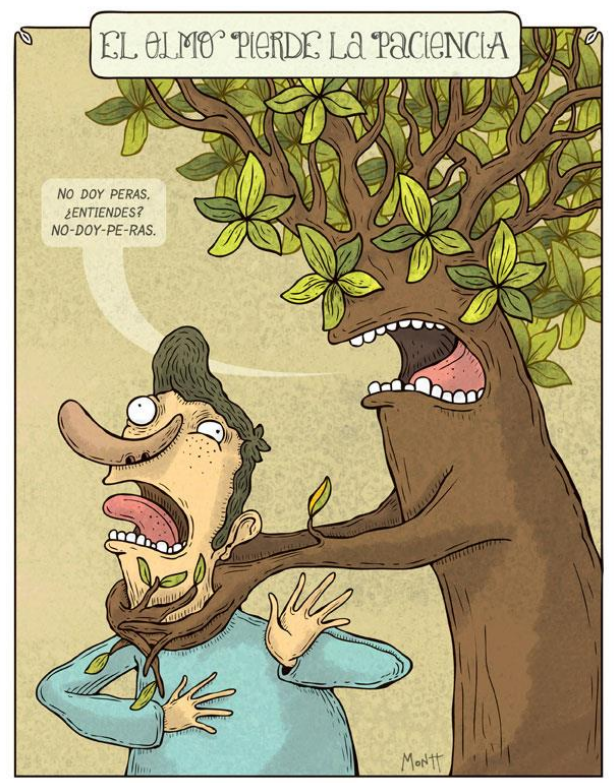

Figure 1. Linguistic and restricted knowledge scripts in C13. Source: http://www.dosisdiarias.com/ Author: Alberto Montt ${ }^{5}$

All participants in this study were students completing a postgraduate university degree (i.e. Master of Teaching Spanish as a Second Language) in one of the two universities approached: Middlebury College (Argentina) and University of Salamanca ${ }^{6}$ (Spain). A total of 36 volunteers were obtained, $18 \mathrm{~L} 2$ users from the Middlebury College and $18 \mathrm{~L} 1$ users from the University of Salamanca. The Spanish language competence of all L2 users was assessed prior to their

\footnotetext{
${ }^{5}$ Creative Commons License: Freedom to share, copy and redistribute the material in any medium or format. Under the following terms: attribution, non-commercial, no derivatives, CC BY-NC-ND.

${ }^{6}$ The identity and information of the participants in this study is protected by the regulations governing the ethical code of research. This study is approved by the Institutional Review Board of Middlebury College. In turn, the approval of the questionnaire was supported by the US National Institute of Health certificate Human Subjects Protection Training that regulates research with human subjects.
} 
enrolment in the master's program and all participants from Middlebury College were judged to be at a $\mathrm{C} 1$ level (i.e. effective operational proficiency level according to the Common European Framework of Reference for Languages). As for all L1 participants, they were assessed as C2 (native mastery) users. Thus, both L1 and L2 participants in this study can be classified as proficient Spanish language users.

The 36 graduate university participants' ages ranged between 23 and 48 years old, with a predominance of female participants (L1: 15 female and 3 males; L2: 18 female and 0 males). It should be noted that the focus of this study is not on gender differences. Comparative studies on humour have observed male/female differences (e.g. Hay 2000; Kotthoff 2000; Martin et al. 2003) including a characteristic female solidarity and self-directed humour with a covert criticism of social norms (Ferreira 2012). However, constructivist approaches regard gender as a sociocultural construct with appropriate female and male behaviour norms that can be challenged, thus contradicting gender stereotypes. As argued by Ferreira (2012: 126), "this tendency to concentrate on difference is a problem of gender and discourse research in general, that entails a reaffirmation of broader gender stereotypes in interactional styles". Furthermore, the predominance of female participants in this study is representative of the markedly higher number of female enrolments in the Humanities in higher education (Graña 2008; Ministerio de Educación, 2010; Bacalini 2017).

In order to explore the potential impact that cartoon characteristics pertaining to contextualisation and content indexes can have on the understanding and appreciation of graphic humour by L1 and L2 users, a survey was designed to gather information on the participants' response to the 14 selected stimuli cartoons. Other validated questionnaires have been used in humour studies; however, those were not used as they were not considered to address all key factors that could hinder or facilitate humour in both the understanding and appreciation processing stages. For example, the Humour Styles Questionnaire (Martin et al. 2003), one of the most widely accepted surveys, measures the psychological dimensions of humour (i.e. affiliative, self-enhancing, aggressive and self-defeating) in the appreciation stage but it does not elicit data on the effect that cartoon textual characteristics can have on both humour appreciation and understanding stages. Thus, the survey used in this study was designed to collect data related to the effect that different kinds of cognitive scripts and structural elements can have on both the understanding and appreciation of graphic humour.

The study survey comprised 52 items and was completed by all L1 and L2 participants. Items 1 to 10 gathered demographic data, and items 11 to 52 explored participants' experience related to processing stages in cartoon humour. For each of the 14 stimuli cartoons, three items (i.e. QA, QB and QC) collected information on the understanding and appreciation stages of humour. Item QA "Value humour in the following cartoon in a scale from [1] (Not funny at all) to [4] (Very funny)" is a Likert-scale item that aimed at identifying whether participants would experience failed or successful humour in the understanding and appreciation phases. Item QB "Why?" was designed as an open question and followed item QA; giving participants the opportunity to describe and develop reasons behind their understanding and/or appreciation of the stimuli cartoon humour. The analysis of the data collected from this item was in turn intended to a) determine what content and structure textual elements attract the attention of participants and affect successful/failed humour; and b) to better understand the nature of emotional and cognitive manifestations of appreciation.

Items QA and QB were followed by item QC, "Would you need more information?" This third and last item eliciting participants' response to each of the stimuli cartoons was intended to gather further information on the understanding stage of humour. Since failed humour is a phenomenon of interest in the study, item QC was specifically included in the survey to explore whether participants' responses to graphic humour could be linked to any of Bell \& Attardo's (2010) categories of failed humour, including those related to semantic and pragmatic variables 
such as their category 2: Unable to understand words/connotations; category 3: Unable to understand the pragmatic meaning; and category 5: Unable to understand the incongruity. Furthermore, according to findings from the General Theory of Verbal Humour (Attardo \& Raskin 1991), developments on script availability (Attardo 1994) and humour research in language acquisition (Schmitz 2002), users need to have access to opposed cognitive scripts in order to successfully process humour. QC item was thus developed as an open question given that it was intended to also tap into perceptions on access to scripts. It should be noted that a request for confirmation of understanding such as "Do you understand this cartoon?" was not included in the survey, given that language users can feel embarrassed to admit a lack of understanding. Explicit metalinguistic judgements by participants, such as admitting ignorance of linguistic or sociocultural content information expected to be known in a text, are among the speech acts that can threaten self-image (Austin 1962; Brown \& Levinson, 1987).

Qualitative discourse content analysis of answers to open questions was expected to provide a deeper understanding of participants' appreciation process. This analysis was carried out to identify keywords in participants' discourse that indicated successful and failed appreciation of humour. Instances of failed appreciation were coded according to Bell \& Attardo's (2010) seven categories of failed humour, as detailed in the introductory section.

In order to achieve internal validity, an interrater participated in the analysis of the cartoon characteristics selected as stimuli for this study (Mackey \& Gass 2005). In the first round of coding, the main researcher coded both the structure and content characteristics of all 14 cartoons. Next, an interrater independently coded all 14 cartoons according to their structure and content characteristics. Similitudes and divergences from both researchers were tabulated and contrasted. Subsequently, any divergences were discussed until agreement in all cases was achieved. The same interrater process that was followed for coding cartoon characteristics was implemented for the validation of the qualitative discourse content analysis of user responses to cartoon humour.

\section{Textual elements that contribute to understanding and appreciation in cartoons}

In answer to research question (1), "What textual elements contribute to humour understanding and appreciation of selected cartoons by L1 and L2 users?", findings indicate that participants identified both constraining and facilitating factors related to the understanding and/or appreciation stages. Our analysis of cartoon understanding and appreciation by Spanish L1 and L2 users shows that similar facilitating and constraining factors related to cartoon content and structure affected both groups of participants (see Table 3). Out of the eleven factors, the two groups reported seven facilitating factors (superiority, relief, incongruity, knowledge resources, empathy, personification, dehumanisation) and one constraining factor (restrictive knowledge scripts) as affecting appreciation and understanding of cartoon humour. 
Table 3. Facilitating and constraining factors in the understanding and appreciation stages

\begin{tabular}{l|c|c|c|c}
\multirow{2}{*}{ FACTORS } & \multicolumn{2}{|c|}{ L1 USERS } & \multicolumn{2}{c}{ L2 USERS } \\
\cline { 2 - 5 } & UNDERSTANDING & APPRECIATION & $\begin{array}{c}\text { UNDERSTANDIN } \\
\text { G }\end{array}$ & $\begin{array}{c}\text { APPRECIATIO } \\
\text { N }\end{array}$ \\
\hline Superiority & & $\checkmark$ & & $\checkmark$ \\
\hline Relief & $\checkmark$ & $\checkmark$ & & $\checkmark$ \\
\hline $\begin{array}{l}\text { Incongruity } \\
\text { Knowledge } \\
\text { resources }\end{array}$ & & & & \\
\hline $\begin{array}{l}\text { Artistic visual } \\
\text { aspect }\end{array}$ & & & & \\
\hline $\begin{array}{l}\text { Personification } \\
\text { Dehumanisatio } \\
\mathbf{n}\end{array}$ & & & & \\
\hline $\begin{array}{l}\text { General } \\
\text { knowledge }\end{array}$ & & & & \\
\hline $\begin{array}{l}\text { Restricted } \\
\text { knowledge }\end{array}$ & & & & \\
\hline $\begin{array}{l}\text { Linguistic } \\
\text { knowledge }\end{array}$ & & & & \\
\hline & & & & \\
\hline
\end{tabular}

Facilitating factor: $\boldsymbol{V}$. Constraining factor: $\boldsymbol{X}$. Contrasts highlighted in grey

Both groups of participants showed difficulty in processing restricted knowledge scripts, while only L2 users reported experiencing difficulties in the understanding stage due to limitations related to linguistic knowledge (see Table 3). In line with the General Theory of Verbal Humour $(\mathrm{GTVH})$, this finding supports the relevance of knowledge scripts, particularly of script opposition ( $\mathrm{SO}$ ) as the most important knowledge resource affecting successful humour response from all participants. Limited access to another knowledge resource, Language (LA), was also reported as affecting humour understanding but as it could be expected, only by L2 users.

Results from the content analysis of the L1 and L2 participant responses also point to the reported facilitating role played by knowledge resources, particularly incongruity (i.e. script opposition) in the appreciation stage. Specifically, as illustrated in Table 4, participants' use of keywords denoting a sense of experienced superiority, relief and identification of incongruity revealed attention to these three humour appreciation triggers in the stimuli cartoons. L1 and L2 participants related their appreciation to the ridicule of characters (superiority), the relief from constraints of social norms and identified an element of disruption or surprise typical of incongruity. 
Table 4. Keywords denoting the three humour appreciation triggers of superiority, relief and incongruity by L1 and L2 participants

\begin{tabular}{|c|c|}
\hline Superiority & $\begin{array}{l}\text { L1: disfuncionales, feos, fealdad, tonto/a, alcohólicos, ridiculez, se mete } \\
\text { con, perspectiva } \\
\text { 'dysfunctional, ugly, ugliness, foolish, alcoholic, ridiculousness, picking on, } \\
\text { perspective' } \\
\text { L2: feos, asco, ayuda, borrachos, necesitado, pobre, secos, sucio } \\
\text { 'ugly, disgust, help, drunkards, needy, poor, dry, dirty' }\end{array}$ \\
\hline Relief & $\begin{array}{l}\text { L1: tabú, crítico, sátira, ácido, humor negro, explícita, burla, ironía/irónica, } \\
\text { controvertida, políticamente incorrecto, incomprensibles, insoportables, } \\
\text { cultura(les), picante, sexual, pedofilia, racismo, socialmente, restrictiva, } \\
\text { nunca, obscenidades, machista } \\
\text { 'taboo, critical, satire, acid, black humour, explicit, mockery, irony/ironic, } \\
\text { controversial, politically incorrect, incomprehensible, unbearable, } \\
\text { culture(s), spicy, sexual, paedophilia, racism, socially, restrictive, never, } \\
\text { obscenities, sexist' } \\
\text { L2: cultura/l, sexual/idad, adultos, (auto)ironía/ico/a, burla, diablo, bruto, } \\
\text { políticamente correcto, criticado, crítico/a, deseos, normas, ofensivo, } \\
\text { pene, problemas, sarcástico, sucio, tabú, tradiciones, vírgenes } \\
\text { 'culture/cultural, sexual/sexuality, adults, (auto)irony/ironic, mockery, } \\
\text { devil, gross, politically correct, criticised, critical, desires, norms, offensive, } \\
\text { penis, troubles, sarcastic, dirty, taboo, traditions, virgins' }\end{array}$ \\
\hline Incongruity & $\begin{array}{l}\text { L1: doble, contradicción, mezcla, resuelve, rompe, da la vuelta, sacado, } \\
\text { original, otra, surrealista, absurdo } \\
\text { 'double, contradiction, mix, solve, break, turn, pull (out of context), } \\
\text { original, another, surreal, absurd' } \\
\text { L2: choque, aunque, contra, diferente, extraño, falta, imposible, } \\
\text { inesperado, otro, raro, problemas, reinterpretación, rompe, sorpresa } \\
\text { 'shock, though, con, different, strange, missing, impossible, unexpected, } \\
\text { another, weird, problem, reinterpretation, breaks, surprise' }\end{array}$ \\
\hline
\end{tabular}

Another element operating as a facilitative factor in our findings is participants' reported attention to the cartoon's empathic agents (i.e. any textual resource that can trigger personal 
relatedness with the characters). As illustrated in Table 5, L1 and L2 participants expressed this emotional reaction through both shared ordinariness (examples of keywords used include común, vida, real, representa, actualidad, compartimos, emoción, normal, pensamientos, personajes, personas, perspectiva, realidad, reconocible, siempre, todos, típico -'common, life, real, represents, nowadays, (we) share, emotion, normal, thoughts, characters, people, perspective, reality, recognisable, always, always, everyone, typical') and positive values (examples of keywords used include verdad, bien, buena). At the visual level, the empathic role played by the personification of cartoon characters was revealed by participants' identification of personifying caricature in the stimuli cartoons (keywords used include diablo, olmo, perros/itos, monitos and peces -'devil, dogs/doggies, little monkeys, fishes'). This finding corroborates similar findings reported in the literature (Keen 2011) supporting the empathic effect that cartoon caricatures can trigger by humanising non-human behaviour. In the present study, dehumanisation caricature is associated with the appreciation trigger factor of superiority whereas personification seems to trigger an empathic response from the reader.

Besides reporting attention to empathic agents and elements that trigger appreciation through superiority, relief and incongruity, L2 participants paid attention to the artistic visual aspect of cartoons. The content analysis of the $\mathrm{L} 2$ participant responses revealed that participants used keywords related to the artistic visual aspect of cartoons (e.g. creativo, colores, arte, artístico, foto, imagen, bonito, gráficamente, retratándolo - 'creative, colours, artistic, photo, image, beautiful, graphically, portraying (it)') to report a positive appraisal and successful appreciation. These results support prior research showing that a realistic style is less appreciated by readers than an exaggerated depiction based on round shapes and caricature (Bonaiuto \& Giannini 2003). This feature seems to have received more attention from L2 participants than from the L1 users, as it is only reported by the L2 group of language users.

Table 5. References to empathy

\begin{tabular}{|l|l|}
\hline $\mathbf{L 1}$ & $\begin{array}{l}\text { identificación(ada/arme/arnos), humana(os), todos/as, real, simpático/a, } \\
\text { comparto, cercana, reflejada, familiar(izados/a), inocente, individualidad, } \\
\text { personas, clásico, exactamente, cuando, hago, mismo, normalito, riquiño, } \\
\text { real(idad/mente), siempre, bien, buenas, socio, vida, mundo, diariamente, } \\
\text { cotidianos(eidad), actual, sensaciones, imagino(ativa) } \\
\text { 'identification/identified/identifying myself/ourselves), human/humans, } \\
\text { everyone, real, friendly, sharing, close, reflected, familiar, innocent, individuality, } \\
\text { people, classic, exactly, when (I) do, same, normal, cute, real/reality/really, always, } \\
\text { well, good, partner, life, world, daily, ordinariness, current, sensations, (I) } \\
\text { imagine/imaginative' }\end{array}$ \\
\hline $\mathbf{L 2}$ & $\begin{array}{l}\text { común, vida, real, representa, actualidad, compartimos, emoción, normal, } \\
\text { pensamientos, personajes, personas, perspectiva, realidad, reconocible, siempre, } \\
\text { sienten/o, tendencia, todos, típico } \\
\text { 'common, life, real, represents, nowadays, (we) share, emotion, normal, thoughts, } \\
\text { characters, people, perspective, reality, recognisable, always, (I/they) feel, trend, } \\
\text { everyone, typical' }\end{array}$ \\
\hline
\end{tabular}


Incongruity, empathic agents, and the visual aspect, including its artistic dimension, all come together in the contextualisation index of personifying caricature. Given that caricature is defined as a distortion, it can be argued that caricature constitutes itself as incongruity. However, as one of the prototypical contextualisation indexes that conforms to a cartoon, caricature does not constitute the main incongruity that shapes the cartoon's intentional meaning but instead, is a secondary incongruity that contributes to the humorous intentional meaning. This reasoning leads us to the possibility of appreciated humour despite not understanding the main incongruity.

To answer research question (2): "Does cartoon appreciation require complete understanding?", participants' responses were analysed quantitatively and qualitatively to indicate humour appreciation despite the lack of complete understanding of four of the 14 stimuli cartoons (i.e. to $\mathrm{C} 02, \mathrm{C} 04, \mathrm{C} 05$ and $\mathrm{C} 12$ ), as reported by four of the $\mathrm{L} 2$ participants. Specifically, four L2 users reported an orientation towards alternative interpretations to the cartoon's intentional meaning by indicating their appreciation despite not completely understanding the intended main incongruity. This finding questions the idea that the understanding stage must precede the appreciation stage (Hay 2001) as previously maintained by Bell (2007).

Overall, L2 users reported more cases of failed humour in the understanding stage than L1 users (see Figure 2). This finding corroborates those reported in other studies pointing out that L2 users tend to fail more in comparison to L1 users (e.g. Bell \& Atttardo 2010).

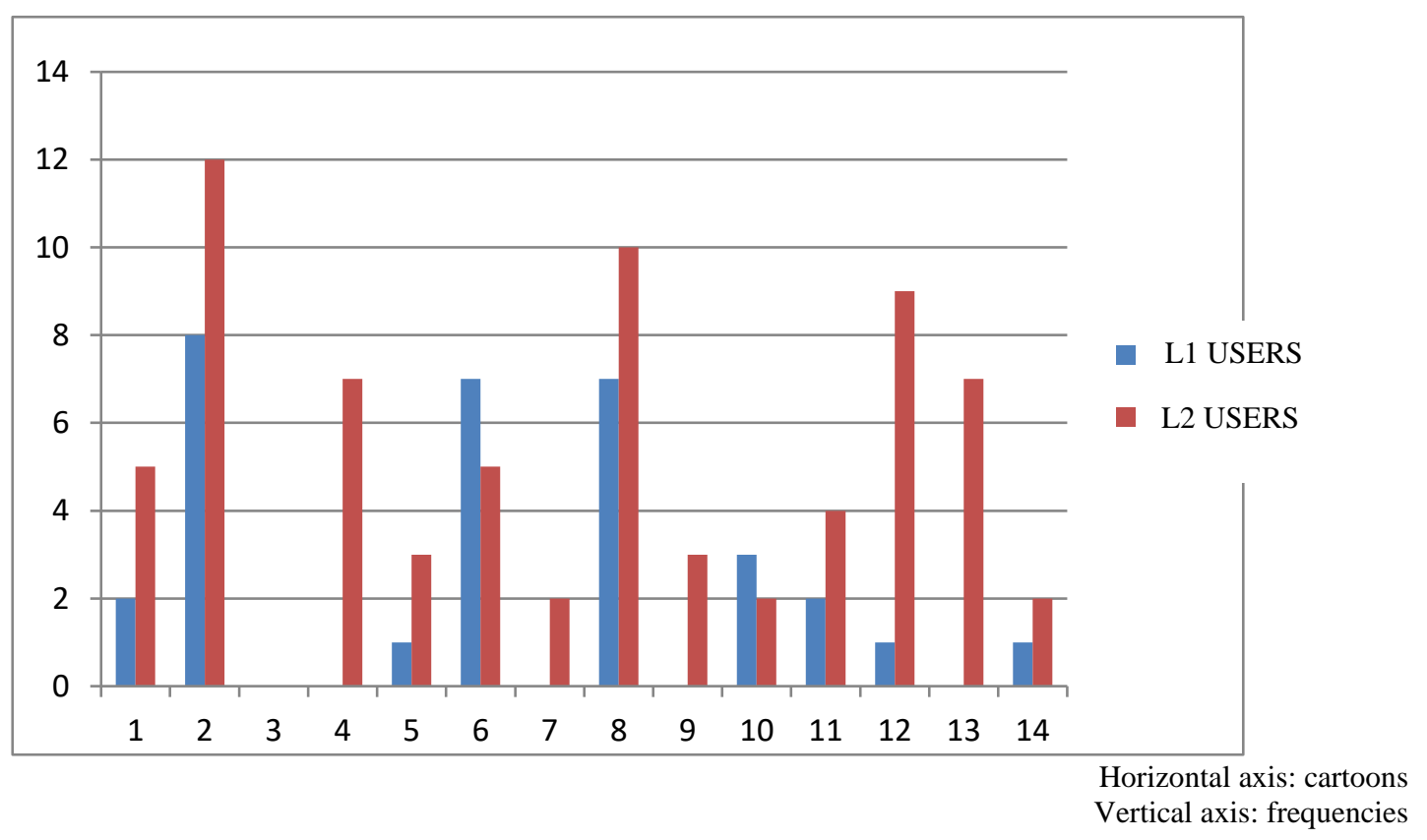

Figure 2. Failed humour in the understanding stage by L1 and L2 participants

The main contributing factors to failed humour affecting both groups of speakers are linked to: 1) lack of access to linguistic content in a foreign language (linguistic knowledge scripts), and 2) lack of access to cultural references (restricted knowledge scripts). Quantitatively, the higher frequencies reported by both groups relate to $\mathrm{C} 02$ and $\mathrm{C} 08$ cartoons (See Table 2 for details on the content and structure elements of the selected 14 cartoons).

Given that the title in cartoon C08 is in Latin, a foreign language for both L1 and L2 Spanish language users, the linguistic characteristic of this cartoon can be assumed to have inhibited the understanding of its humorous meaning of both the L1 and L2 participants. 
As for the higher frequencies of failed humour due to cultural references (i.e. above 6 instances), we observe a relatively higher number of instances reported by reported by both L1 and L2 participants in response to the $\mathrm{C} 02$ ( 8 and 12 instances respectively) and the $\mathrm{C} 06$ ( 7 and 5 instances respectively) humorous intent. At first glance, the high frequencies of L1 failed understanding of $\mathrm{C} 02$ and $\mathrm{C} 06$ could be deemed unexpected. This finding could be better understood given the specific type of restricted knowledge script that both cartoons present.

As pointed out in the methodology section, two differentiated types of restricted knowledge scripts have been identified in the literature: sociocultural knowledge and encyclopaedic knowledge scripts. To understand the humorous meaning in $\mathrm{C} 02$, users need to be acquainted with how homeopathy is alleged to work. This type of knowledge could be assumed to be only familiar to those who have an interest in alternative health practices rather than to any specific Spanish-speaking cultural knowledge. Similarly, the nature of the cultural knowledge required to understand the humorous meaning in $\mathrm{C} 06$ is not related to sociocultural knowledge specific to Spanish-speaking communities. C06 is a cartoon presenting encyclopaedic knowledge, given that the reader needs to know how achromatopsia (colour blindness) operates (i.e. decreased ability to recognise colours). Thus, regarding $\mathrm{C} 02$ and $\mathrm{C} 06$, relatively high frequencies of reported failed understanding of humour by L1 and L2 users can be better understood when we take into consideration the fact that these two cartoons contain encyclopaedic knowledge and, as such, they can present a challenge to both cohorts of participants, regardless of their sociocultural context.

In contrast, in order to successfully understand the humour in $\mathrm{C} 13$, the reader needs to be acquainted with the linguistic and, importantly, the sociocultural knowledge script that this proverb presents. That is, beyond the semantic meaning of the lexical units olmo ('elm') and peras ('pears') used in the text of $\mathrm{C} 13$, the reader needs to access the meaning of these lexical terms as a unique phraseological unit that belongs to the Spanish-speaking cultural heritage (see Mieder 2008). It is thus not surprising that failed understanding of humour in relation to C13 is exclusively reported by the L2 participants.

It should be noted, however, that, in this study, L2 users' failed humour differs not only in quantitative but also in qualitative terms. A lack of partial or complete access to linguistic and cultural scripts present in the cartoons was evidenced in the L2 participants' self-reported data. In addition, cases of appreciation, despite a lack of complete understanding, were only reported by the L 2 cohort. This data points to another qualitative difference, namely, the redirection of attention to alternative interpretations when lacking access to the scripts that create the main incongruity. On that account, we argue that quantitative data should not be considered separate from qualitative data when analysing responses to humour.

\section{Discussion}

Findings presented in this paper show that textual elements relative to content (i.e. restrictive knowledge scripts and linguistic knowledge scripts) and contextualisation indexes (i.e. caricature) affect communication of the humorous intent in multimodal humour. Our data documents facilitating elements (i.e. knowledge resources, superiority, relief, incongruity and empathic agents) that tilt the balance towards successful humour while constraining elements (i.e. partial or no access to knowledge scripts, particularly to restrictive knowledge scripts) explain differing responses by L1 and L2 users and failed humour.

The main contribution of this study lies in its provision of a comprehensive picture of the different elements that contribute to successful and failed humour that have not been fully considered by traditional pragmatic approaches. In pragmatic research, incongruity has been identified as the exclusive source of humour appreciation (Koestler 1969; Nerhardt 1976; 
Attardo 2014). In contrast, this investigation reveals that participants' attention was not only turned towards cartoons' incongruous elements indicating a clash between two cognitive scripts or an experienced surprise (keywords used include: choque, doble, contradicción, sorpresa, inesperado, reinterpretación -'clash, double, contradiction, surprise, unexpected, reinterpretation'), but also to superiority and relief elements accounting for successful cartoon appreciation. Specifically, participants experienced a sense of superiority conveyed through negative adjectivations of the cartoon characters (keywords used include: disfuncionales, feos, tonto/a, alcohólicos, borrachos, pobre, secos, sucio -'dysfunctional, ugly, stupid, alcoholic, drunk, poor, dry, dirty') positioning the reader on a superior plane above those same characters. L1 and L2 users also indicated that the content of cartoons provided a break from social constraints related to taboo and controversial topics (keywords used include: tabú, ácido, humor negro, controvertida, politicamente incorrecto, sexual, racismo, obscenidades, machista, normas, ofensivo -'taboo, acid, black humour, controversial, politically incorrect, sexual, racism, obscenities, sexist, norms, offensive'). It can thus be stated that relief was identified by L1 and L2 users as a factor conducive to appreciation. Although these elements have been previously reported in studies framed under one of the three major theories of humour (i.e. incongruity theory, superiority theory and relief theory), our findings indicate that these elements are not only present but also coexist in cartoons, as also argued by Milner Davis (2015) in reference to humour texts.

Our data also question the ability of the relevance and cooperation principles to regulate all communication instances alone. From the perspective defended by the relevance and cooperation theories, successful humour communication relies on the reader being able to identify and resolve the main incongruity present in script opposition. Given the compatibility between the relevance principle and the incongruity theory, relevance has often been used to explain humour processing and incongruity has been identified as the main source of humour appreciation (see Shultz \& Horibe 1974; Hempelmann \& Attardo 2011).

In contrast, our data indicate that L2 participants appreciate the humorous intent in the selected cartoons despite a lack of understanding. Specifically, four of the L2 users reported humour appreciation even when experiencing and reporting constrained access to linguistic and restrictive knowledge scripts at the textual level. Our L2 user data demonstrate that constraining factors were resolved at the visual level, resulting in cartoon appreciation despite not identifying the main incongruity. In particular, the appreciation of artistic elements, the establishment of emphatic connections and the presence of secondary incongruities were revealed as factors that enabled cartoon appreciation. Indeed, the literature has identified cartoon characteristics related to the artistic dimension that boost humour appreciation (see Hempelmann \& Samson 2008; Samson 2008). Furthermore, various studies on multimodal texts and cartoons have reported a successful emotional connection between the reader and the characters, attributing an empathic function to caricature techniques such as personification (see Minahen 1997; Keen 2011). In line with this research, our L2 data indicate that caricature, as a key aesthetic element in the structure and content of cartoons, is conducive to successful humour (see keywords used as reported in the results section (e.g. creative, colores, arte, artístico, foto, imagen, bonito, gráficamente, retratándolo -'creative, colours, art, artistic, photo, image, beautiful, graphically, portraying (it)').

Moreover, caricatures and round shapes have been identified in humour research as being more appreciated than realistic depictions (Boniauto \& Giannini 2003), pointing to the potential of caricature to establish an empathic connection with the reader through portrayed facial expressions (McCloud 1993). This connection highlights the central role of empathy, underlining the relevance of emotional allegiance and identification with characters. In our study, the stimuli cartoons featured these characteristics and proved to trigger participants' positive affective disposition in the form of empathy. That is, an audience's social allegiance to 
the cartoon characters can play an important role in user appreciation based on an emotional connection with the cartoons characters, as reported by both the L1 and L2 participants. Therefore, our findings are in line with Warren \& McGraw's (2014) premise that humour appreciation encompasses not just physical responses (laughter) or cognitive responses (value judgement) but also emotional responses and identifies empathy as an emotional manifestation of appreciation. Specifically, L1 and L2 participants' appreciation responses to graphic humour linked dehumanisation to an experienced sense of superiority and personification to triggered empathy.

On the other hand, it cannot be ruled out that a potential need for social acceptance among L2 participants could have played a role in their reported appreciation of cartoon humour. As suggested by Kramsch (1997), L2 users may experience implicit pressure to be considered as insiders in the language community. This could, in turn, have redirected participants' attention to the cartoons' secondary incongruities as a tactic to tackle communication obstacles such as partial or total lack of access to linguistic and/or restrictive knowledge scripts.

Notwithstanding a potential lack of appreciation due to L2 users' limited access to knowledge scripts, studies in humour cognition indicate that humour appreciation may be prompted by incongruity without a resolution. This has been found to be the case when caricature, slapstick and children's humour is used (Forabosco 2014). According to the General Theory of Verbal Humour (Attardo \& Raskin 1991), the intentional meaning is shaped through the main incongruity present in script opposition; therefore, when the intentional meaning is not accessed but appreciation is still achieved, it could be assumed that other elements, such as the presence of caricature, may facilitate humour appreciation. That is, since caricature does not constitute the main incongruity shaping a cartoon's intentional meaning, we believe that the personifying caricatures depicted in the stimuli cartoons selected for this study functioned as secondary incongruities that prompted appreciation of multimodal humour.

We argue that the very existence of appreciation, even if it does not resolve the main incongruity in script opposition, reveals that the L2 users independently evoked an alternative interpretation of the humorous intent that, in turn, triggered successful humour, even when the cartoon's main incongruity was not understood. In other words, caricature, as a secondary incongruity, may explain the independent interpretation reported by the L2 participants when attention was not oriented towards the cartoon's intentional meaning. This finding provides support for the adoption of a socio-cognitive approach to the study of multimodal humour appreciation, given that it is only when we consider both individual and societal factors, such as attention and cooperative intention respectively, that we gain a comprehensive picture of the tension between successful and failed appreciation of multimodal humour in cartoons.

\section{Conclusions}

Taken together, our findings highlight the role that cartoon aesthetic aspects have in successful humour responses, particularly in enabling L2 users' appreciation of multimodal humour despite gaps in the understanding phase. This finding aligns with social-behavioural theories in psychology that propose that humour appreciation is a question of emotional relevance and attention when processing humour texts (Freud 1905; Mead 1934; Roberts \& Johnson 1957; LaFave 1972;). From this standpoint, a joke is "humorous to the extent that it enhances an object of affection and/or disparages an object of repulsion; unhumorous to the extent that it does the opposite" (Lafave 1972: 198). In a similar vein, within humour research, studies on caricature have argued that personification allows empathising with cartoon characters, whereas dehumanisation puts the reader in a superior perspective (Minahen 1997; Keen 2011). 
This investigation further reveals the differing roles of caricature not only in the recognition stage but also in the understanding and appreciation stages. As illustrated in Figure 3, our data demonstrates that caricature can function as a secondary incongruity and also trigger emotional appreciation, thus playing an important role in the successful recognition, understanding and appreciation of cartoons. Previous studies have identified the structural role of caricature as a contextualisation index, as one of the prototypical features of cartoons that activates genre expectations in the recognition stage ${ }^{7}$ (Padilla \& Gironzetti 2012). These authors also identified a content index role of caricature operating during the understanding stage by activating the cartoon's topic when caricature featured a celebrity. In this study, caricature has been found to have a threefold effect in successful graphic humour by: i) enabling recognition of the humorous intent; ii) embodying an inherent secondary incongruity given their distorted representation of reality and iii) eliciting an empathic/deprecating emotional response.

The present study has therefore identified two additional roles: caricature functioning as a secondary incongruity and triggering emotional appreciation. As a secondary incongruity, it can enable resolution when users focus their attention on the artistic visual aspect of caricature while as an emotional factor in humour appreciation, it can take place in the form of empathy towards humanised characters or disdain for deformed human characters. It can thus be asserted that our research contributes to the study of caricature by proposing a) a distortion-oriented caricature typology and b) identifying two novel roles of caricature to those previously identified as part of contextualisation indexes in humour research.

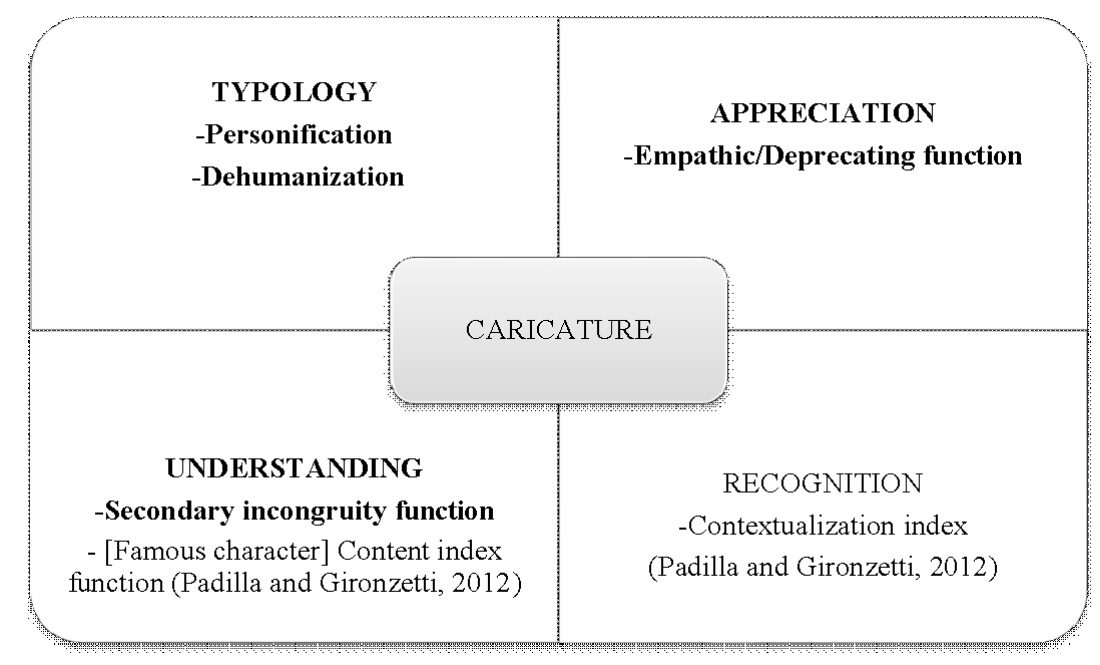

Figure 3. Contributions to the concept of contextualisation index (in bold letters)

From a second language learning perspective, studies in humour predominantly indicate that access to cultural, linguistic, and individual scripts condition humour understanding and appreciation by L2 users (see Attardo 1994; Schmitz 2002). Limitations in cultural knowledge and linguistic resources are both pointed as underlying issues in humour understanding and as having a negative impact on its appreciation. However, as has been argued by Bell (2007) and confirmed by the results of the present study, language users do not need to fully understand a humorous text to appreciate it. In fact, findings from this investigation support Bell's (2007) dynamic model of humour competence, while challenging the lineal version proposed by Hall (2001), as appreciation of humour by L2 users was found to occur despite gaps in the understanding stage.

\footnotetext{
${ }^{7}$ See Canestrari (2010), who adds the meta-knowledge resource to GTVH knowledge resources. Among these elements are frame, caricature, signature, and subtitle.
} 
Individual factors affecting appreciation have also been linked to a language user's private experience (Gil 2019). Subsequently, research in L2 failed humour has mainly focused on the cultural references that users may be missing when processing texts because of the L2 users' lack of access to some cognitive scripts in their cognitive environment. This view squarely considers failed humour appreciation of cultural knowledge solely on the basis of failed understanding. That is, the interlocutor's cognitive environment or actual situational experience defines the ability to identify the cartoonist's intention without considering the user's private experience, understood as "the unique and unrepeatable individual's cognitive system, which organises what has been learnt and determines both linguistic production and linguistic understanding" (Gil 2019:178). Notwithstanding the determining role played by the actual situational experience in the successful understanding of restricted knowledge scripts, little consideration has been given to the importance of private experience, salience and attention in cartoon appreciation. Indeed, when successful appreciation relies on sharing a similar cultural background and personal experience, our data shows that failed appreciation may not be due to a lack of understanding but to the inability of the reader to personally relate to the specific background experience.

Hence, we argue that graphic humour can only be successfully understood from a sociocognitive approach that considers both intention and attention-oriented practice. In our study, a balance between intention-oriented practice and attention-oriented practice was considered to explain the fundamental role that empathy has in successful graphic humour. Our findings reveal that empathy played a central role in cartoon appreciation when users' attention-oriented practice was reported to be directed at how relatable the characters in the cartoons were. In other words, empathy was reported to be triggered when participants self-identified with the depicted characters. That is, the emphasised features elicited a positive affective disposition towards the characters, and this in turn fostered the participants' sense of empathy. Hence, the common disgust that humans tend to feel towards rats and mice, creatures that do not share a similar physiognomy with us, is in blatant contrast with the sympathy and overall positive feelings that other personified creatures such as Mickey Mouse do evoke. Indeed, keywords reported by participants that denote empathy highlight the connection that caricatures created with L1 and L2 users through identity relations in the form of personification and dehumanisation (e.g. identificacion, reflejada, comparto, representa, reconocible -'identification, reflected, (I) share, represents, recognisable'). Most particularly, we found that it is crucial to understand the relevance of personification as a type of caricature that promotes empathy towards non-human characters in the recognition, understanding and appreciation of cartoons, given that caricatures can elicit an emotional response in the reader, while maintaining a primary humoristic function. This is a noteworthy finding given that, despite a partial or complete lack of humour understanding among L2 users, empathy can promote successful cartoon appreciation that, in turn, may also affect motivation in the context of second language learning.

Given the exploratory nature of this project, some limitations should be noted. In order to contribute to a better understanding of the elements and tactics involved in the appreciation of cartoon humour, the participant sample needs to be widened in order to expand the range of L1 and L2 users insights. The adoption of mixed methods employing complementary data sources, particularly interviews, could also strengthen the potential of analyses exploring how different factors may interact in the three humour stages.

Aside from these shortcomings, our study provides a comprehensive analysis of different factors affecting successful and failed multimodal humour, and documents empathy as an emotional manifestation of appreciation of cartoon humour. Future investigations should focus not only on main incongruities, as proposed by canonical pragmatic approaches, but also regard 
factors that could draw the attention of language users, such as secondary incongruities and empathic agents.

In addition, humour research adopting a socio-cognitive approach in the context of second or foreign language teaching and learning could explore whether the distortion-oriented caricature typology we propose can be applied in the use of humour for SLA. We suggest investigating whether learning activities designed to facilitate the identification of central and secondary incongruities in cartoons may benefit language learners' development of humour understanding and appreciation. This line of enquiry within second language learning research could explore how different processes involved in the identification of secondary incongruities can be promoted for successful appreciation by second or foreign language learners.

\section{Acknowledgements}

The authors wish to express their gratitude to the cartoonist Alberto Montt for granting us permission to reproduce his cartoon in this article, as well as to the students who participated in this study and the anonymous reviewers for their comments on this article.

\section{References}

Aristóteles (1974). Poética (V. García Yebra, trad.). Madrid: Gredos.

Attardo, S. (2014). 'Incongruity and resolution', in Attardo S. (ed.), Encyclopedia of Humour Studies (Vol. 1). Thousand Oaks, CA: Sage Publications, pp. 383-385.

Attardo, S. (2002). 'Humour and irony in interaction: From mode adoption to failure of detection', in Anolli, L., Ciceri, R \& Riva G. (eds.), Emerging Communication 3, pp.159180.

Attardo, S. (1994). Linguistic Theories of Humour. Berlin: Mouton de Gruyter.

Attardo, S. (1993). 'Violation of conversational maxims and cooperation: The case of jokes'. Journal of Pragmatics 19 (6), pp. 537-558.

Attardo, S. \& Raskin V. (1991). 'Script theory revis(it)ed: joke similarity and joke representation model'. Humour: International Journal of Humour Research, 4(3-4), pp.293-347.

Austin, J. L. (1962). Cómo Hacer Cosas con Palabras. Barcelona: Paidós.

Bacalini, F. (2017). 'Mujeres y universidad: Cronología de una inclusión (matizada)'. Sociales \& Virtuales 4 (4) Retrieved April, 23, 2019 from http://socialesyvirtuales.web.unq.edu.ar/mujeres-y-universidad-cronologia-de-unainclusion-matizada/

Bakhtin, M. M. (1984). Rabelais and his World (H. Iswolsky, trad.) H. Bloomington: Indiana University Press.

Bartolo, A., Benuzzi, F., Nocetti, L., Baraldi, P., \& Nichelli, P. (2006). 'Humour comprehension and appreciation: An fMRI study'. Journal of Cognition Neuroscience 18 (11), pp. 17891798.

Bell, N. D. (2015). We Are not Amused. Failed Humour in Interaction. Berlin/Boston: De Gruyter Mouton

Bell, N. D. (2014). 'Failed humour', in Attardo, S. (ed.), Encyclopaedia of Humour Studies (Vol. 1). Thousand Oaks, CA: Sage Publications, pp. 231-233.

Bell, N. D. (2013). 'Responses to incomprehensible humour'. Journal of Pragmatics 57 (1), pp.176-189.

Bell, N. D. (2009). 'Responses to failed humour'. Journal of Pragmatics 41 (9), pp.1825-1836. 
Bell, N. D. (2007). 'How native and non-native English speakers adapt to humour in intercultural interaction'. Humour: International Journal of Humour Research 20 (1), pp. 27-48.

Bell, N. D., \& Attardo, S. (2010). 'Failed humour: Issues in non-native speakers' appreciation and understanding of humour'. Intercultural Pragmatics 7 (3), pp. 423-447.

Bell, N. D. (2002). Using and Understanding Humour in a Second Language: A Case Study. Michigan: University of Pennsylvania

Bergson, H. (1911 [1899]). Laughter: An Essay on the Meaning of the Comic. New York: Macmillan.

Bonaiuto, P., \& Giannini, A. M. (Eds.) (2003). Selezione di Contributi di Psicologia dello Humor. Roma: E.U.R.

Brown, P. \& Levinson, S. (1987). Politeness: Some Universals in Language Usage. Cambridge: Cambridge University Press.

Carbajal-Carrera, B. (2015). 'Dogsbody. An overview of transmorphic techniques as a humour device in cartoons and its impact on Alberto Montt's work', Philament, 20, pp. 79-104.

Carbajal-Carrera, B. (2013). 'Grados de espontaneidad en el humor. Implicaciones del caso de la viñeta en el reconocimiento y apreciación de los mensajes humorísticos', Pragmalingüística 21, pp. 41-58.

Carbajal-Carrera, B. (2012). 'Me parto y me mondo. Estudio pragmático-discursivo del chiste aplicado a la clase de ELE'. Redele, 13. Retrieved March 12, 2019 from https://www.educacionyfp.gob.es/educacion/mc/redele/bibliotecavirtual/numerosanteriores/2012/memoria-master/beatriz-carbajal.html

Carretero-Dios H., Pérez, C., and Buela-Casal G. (2010). 'Assessing the appreciation of the content and structure of humour: Construction of a new scale'. Humour: International Journal of Humour Research 23 (3), pp. 307-325.

Council of Europe (2002). Marco común europeo de referencia para las lenguas: Aprendizaje, enseñanza, evaluación. Retrieved March 20, 2019 from http://cvc.cervantes.es/ensenanza/biblioteca_ele/marco/cvc_mer.pdf

Drew, P. (1987). 'Po-faced receipts of teases'. Linguistics 25 (1), pp. 219-253.

Edwards, J.L. (2014). 'Cartoons', in Attardo, S. (ed.), Encyclopaedia of Humour Studies (Vol. 1). Thousand Oaks, CA: Sage Publications, pp. 112-116.

Ferreira, A. V. A. (2012). 'The humorous display of transgressor femininities: 'Sharing a laugh' in Spanish/Galician friendly talk among young women'. Sociolinguistic Studies 6 (1), pp. 121-147.

Forabosco, G. (2014). Cognitive aspects, in Attardo, S. (ed.), Encyclopaedia of Humour Studies (Vol. 1). Thousand Oaks, CA: Sage Publications, pp. 135-138.

Freud, S. ([1905] 1967): 'El Chiste y su Relación con lo Inconsciente'. Obras Completas (L. López Ballesteros, trad.) (Vol. 1), Madrid: Biblioteca Nueva, pp. 825-937.

Genette, G. (2001). Paratexts: Thresholds of Interpretation. Cambridge: Cambridge University Press.

Gil, J. M. (2019). 'A relational account of communication on the basis of slips of the tongue'. Intercultural Pragmatics 16 (2), pp. 153-183.

Gironzetti, E. (2013). Un Análisis Pragmático-Experimental del Humor Gráfico. Sus Aplicaciones al Aula de ELE. Alicante: University of Alicante PhD thesis.

Graña, F. (2008). 'El asalto de las mujeres a las carreras universitarias "masculinas": Cambio y continuidad en la discriminación de género'. Praxis Educativa 12, pp. 77-86.

Grice, H. P. (1975). 'Logic and conversation'. Syntax and Semantics (Vol. 3), New York: Academic Press, pp. 41-58.

Gruner, C. R. (1978). Understanding Laughter: The Workings of Wit and Humour. Chicago: Nelson-Hall. 
Gutiérrez Ordóñez, S. (2006). 'Ejercitarás la competencia pragmática', in Álvarez, A., Barrientos, L., \& Brana, M. (eds.), Las Destrezas Orales, la Competencia Pragmática y la Enseñanza del Español como Lengua Extranjera. Oviedo: University of Oviedo, pp. 25-44.

Haugh, M. (2008). 'Intention in pragmatics'. Intercultural Pragmatics 5 (2). 99-110.

Hay, J. (2001). 'The pragmatics of humour support'. Humour: International Journal of Humour Research 14 (1), pp. 55-82.

Hay, J. (2000) 'Functions of humour in the conversations of men and women'. Journal of Pragmatics 32, pp. 709-742.

Hay, J. (1994). 'Jocular abuse patterns in mixed-group interaction'. Wellington Working Papers in Linguistics 6, pp. 26-55.

Hempelmann, C. F., \& Attardo, S. (2011). 'Resolutions and their incongruities: Further thoughts on logical mechanisms'. Humour: International Journal of Humour Research 24 (2), pp. 125-149.

Hempelmann, C. F., \& Ruch, W. (2005). '3 WD meets GTVH: Breaking the ground for interdisciplinary humour research'. Humour: International Journal of Humour Research 18 (4), pp. 353-387.

Hobbes, T. (1812). A Treatise on Human Nature and That on Liberty and Necessity. London: J. Johnson and Co.

Iglesias Casal, M. I. (2007). 'Estrategias de transgresión del discurso humorístico: decir, querer decir e interpretar', in Álvarez, A., Barrientos, L., \& Brana, M. (eds.), Las Destrezas Orales, la Competencia Pragmática y la Enseñanza del Español como Lengua Extranjera (Vol. 1). Logroño: University of La Rioja, pp. 633-649.

Kecskes, I. (2010). 'The paradox of communication: Socio-cognitive approach to pragmatics'. Pragmatics and Society 1 (1), pp. 50-73.

Keen, S. (2011). 'Fast tracks to narrative empathy: Anthropomorphism and dehumanisation in graphic narratives'. Substance 40 (1), pp. 124-137.

Koestler, A. (1969). The Act of Creation. London: Pan Books.

Kramsch, C. (1997). 'The privilege of the nonnative speaker'. PMLA. Publications of the Modern Language Association of America 112 (3), pp. 359-369.

Lafave, L. (1972). 'Humour judgments as a function of reference groups and identification classes', in Goldstein, F. H. \& McGhee, P. E. (eds.), The Psychology of Humour: Theoretical Perspectives and Empirical Issues, New York: Academic Press, pp. 195-210.

Leech, G. N. (1983). Principles of Pragmatics. London: Longman.

Light S. N., Coan J. A., Zahn-Waxler C., Frye C., Goldsmith H. H. \& Davidson R. J. (2009). 'Empathy is associated with dynamic change in prefrontal brain electrical activity during positive emotion in children'. Child Dev 80, pp. 1210-1231.

Lockyer, S. \& Pickering, M. (2001). 'Dear shit-shovellers: Humour, censure and the discourse of complaint', Discourse \& Society 12, pp. 633- 651.

Mackey, A., \& Gass, S. M. (2005). Second language research: Methodology and design. New York: Routledge.

Martin, R. A. (2007). The Psychology of Humour: An Integrative Approach. Burlington: Elsevier Academic Press.

Martin, R. A., Puhlik-Doris, P., Larsen, G., Gray, J., \& Weir, K. (2003). 'Individual differences in uses of humor and their relation to psychological well-being: Development of the humour styles questionnaire'. Journal of Research in Personality 37, 48-75.

McCloud, S. ([1993] 2009). Entender el Cómic: El Arte Invisible. Bilbao: Astiberri.

Mead, G. H. (1934). Mind, Self and Society. Chicago: University of Chicago Press.

Mieder, W. (2008). "Proverbs Speak Louder than Words": Folk Wisdom' in Art, Culture, Folklore, History, Literature and Mass Media. New York: Peter Lang. 
Milner Davis, J. (2015). 'Australasian humour master class. Investigating humour and Laughter: Trans-disciplinary approaches'. Paper presented at the 21st Australasian Humour Studies Network Conference. Adelaide, 7 February.

Minahen, Ch. D. (1997). 'Humanimals and antihumans in Gary Larson's gallery of the absurd', in Ham, J. \& Senior, M. (eds.), Animal Acts: Configuring the Human in Western History, London: Routledge, pp. 231-251.

Ministerio de Educación (2010). Estadística Alumnado Universitario. Avance de la Estadística de Estudiantes Universitarios. 2008-2009. 2008-2009. Retrieved April 23, 2019 from: http://www.educacion.es/educacion/universidades/estadisticasinformes/estadisticas/alumnado.html

Neale, S. (1980). Genre. London: British Film Institute Publishing.

Nerhardt, G. (1976). 'Incongruity and funniness: Towards a new descriptive model', in Chapman, A. J. \& Foot, H. C. (eds.), Humour and Laughter: Theory, Research and Applications, New York: Wiley and Sons, pp. 55-62.

Padilla García, X. A., \& Gironzetti, E. (2012). 'Humor e ironía en las viñetas cómicas periodísticas', in M. E. Plasencia, \& C. García (Eds.), Pragmática y Comunicación Intercultural en el Mundo Hispanohablante. Amsterdam: Rodopi, pp. 93-133.

Paltridge, B. (1995). 'Working with genre: A pragmatic perspective'. Journal of Pragmatics 23, pp. 393-406.

Priego-Valverde, B. (2009). 'A double voicing analysis'. Humour in Interaction 182, pp. 165186.

Raskin, V. (1985). Semantic Mechanisms of Humour. Dordrecht: D. Reidel.

Ritchie, G. (2013). 'Incongruity-based descriptions of humour'. Paper presented at the 13th International Summer School on Humour and Laughter: Theory, Research and Applications. Otto-von-Guericke-Universität, Magdeburg, 22-27 July.

Roberts, A. F., \& Johnson, D. M. (1957). 'Some factors related to the perception of funniness in humor stimuli'. The Journal of Social Psychology 46 (1), pp. 57-63.

Ruch, W., Attardo, S., \& Raskin, V. (1993). 'Toward an empirical verification of the theory of verbal humour'. Humour: International Journal of Humour Research 6 (2), pp. 123-136.

Ruch, W., \& Platt, T. (2012). 'Separating content and structure in humour appreciation: The need for a bimodal model and support from research into aesthetics', in Nijholt, A. (ed.), Proceedings of the 3rd International Workshop on Computational Humour. Enschede, Netherlands, pp. 23-28.

Ruiz Gurillo, L. (2012). La Lingüística del Humor en Español. Madrid: Arco/Libros.

Schmitz, J. R. (2002). 'Humour as a pedagogical tool in foreign language and translation courses'. Humour: International Journal of Humour Research 15 (1), pp. 89-113.

Shultz, T. R, \& Horibe, F. (1974). 'Development of the appreciation of verbal jokes'. Developmental Psychology 10, pp. 13-20.

Spencer, H. (1911). 'On the physiology of laughter'. Essays on Education, etc. London: Dent.

Spitzberg, B. H. (2000). 'A model of intercultural communication competence', in L. A. Samovar \& R. E. Porter (Eds.), Intercultural Communication: A Reader. Belmont: Wadsworth, pp. 375-387.

Taylor, J. M. (2014). 'Computational humour', in Attardo, S. (ed.), Encyclopaedia of Humour Studies (Vol. 1). Thousand Oaks, CA: Sage Publications, pp. 169-172.

VandenBos, G. R., \& American Psychological Association. (2007). APA dictionary of psychology. Washington, DC: American Psychological Association.

Viana, A. (2010). 'Asymmetry in script opposition'. Humour: International Journal of Humour Research 23 (4), pp. 505-526. 
Warren, C., \& McGraw, A. P. (2014). 'Appreciation of humour', in Attardo. S. (Ed.), Encyclopaedia of Humour Studies (Vol. 1). Thousand Oaks, CA: Sage Publications, pp. 5255.

Watson Todd, R. (2012). 'Creating humour in Gary Larson's Far Side cartoons using interpersonal and textual metafunctions', in Bramlett, F. (ed.), Linguistics and the Study of Comics, New York: Palgrave Macmillan, pp. 37-58.

Zigler, E., Levine, J., and Gould, L. (1967). 'Cognitive challenge as a factor in children's humour appreciation’. Journal of Personality and Social Psychology 6, pp. 332-336. 